\title{
TEACHERS' UNDERSTANDING AND PRACTICES IN ASSESSING HIGHER ORDER THINKING SKILLS AT PRIMARY SCHOOLS \\ Elin Driana $^{1)}$, Ernawati ${ }^{2}$ \\ ${ }^{1)}$ Sekolah Pascasarjana Universitas Muhammadiyah Prof. Dr. HAMKA Jakarta \\ 1)elin.driana@uhamka.ac.id, ${ }^{2}$ ernawati.pep@uhamka.ac.id
}

\begin{abstract}
The aim of this research was to explore primary school teachers' understanding about higher order thinking skills (HOTS), its implementation in classroom assessments, and the quality of the HOTS assessment instrument constructed by the teachers. This qualitative research that was conducted from August to December 2018 involved 10 public and private primary school teachers in Jakarta and it is surrounding areas. Data about the teachers' understanding of HOTS and how teachers applied the assessment of HOTS were obtained through semi-structured interviews. Meanwhile, the quality of the HOTS assessment instrument constructed by the teachers was analyzed to assess its alignment with basic competencies which have become the purpose of learning and the revised Bloom's taxonomy to determine the level of cognitive process in each item. The research results showed that the primary school teachers that participated in this research have not had a comprehensive understanding of HOTS. The majority of the HOTS items that they made were still limited to analysis in the form of multiple choice items. There were also misunderstandings about the HOTS items. In general, the HOTS instrument constructed by the primary school teachers had good content validity, but there was a difference regarding the cognitive process involved in the items the between the perception of the teachers and the perception of the expert. Teachers had the tendency to perceive the items that they have made as HOTS items, although those items were categorized as remembering and understanding. This difference in perception occurred because the teachers did not have a comprehensive understanding of HOTS yet.
\end{abstract}

Keywords: Teachers' understanding, higher order thinking skills, assessment instrument, primary school

\section{INTRODUCTION}

The rapid development of knowledge and technology has resulted in a variety of jobs and social interaction patterns that are different from previous eras. The challenges and problems that humans will face in the future will also become more complex, thus they cannot always be solved by routine procedures. Because of this, the world of education also has to prepare itself to face these changes, such as equipping students with higher order thinking skills (HOTS).

According to Bloom's revised taxonomy, the cognitive process is a continuum that starts from the lowest to the highest, which are remembering, understanding, applying, analyzing, evaluating, and creating (Anderson, et al., 2001). Remembering and understanding are categorized as lower order thinking skills, while applying, analyzing, evaluating, and creating are categorized as higher order thinking skills (Aksela, 2005; FitzPatrick \& Schulz, 2015).

Brookhart (2010) defined the higher order thinking skills into three categories which are transfer, critical thinking, and problem solving. Transfer is a student's ability in understanding and using the knowledge and skills that they have learned in a new context. Critical thinking 
includes the skills of "reasoning, questioning and investigating, observing and describing, comparing and connecting, finding complexity, and exploring viewpoints (Brookhart, 2010, p. 4). Meanwhile, problem solving refers to the skills of using knowledge and thinking skills that a person has to look for new, alternative solutions to problems. Resnick (1987) as stated in Zohar (2004) mentioned the characteristics of higher order thinking which are: non-algorithmic, complex, with multiple solutions, multiple criteria, and uncertain.

The education reforms happening in many countries show a shift in teaching, from emphasizing on lower order thinking skills (LOTS) to emphasizing on higher order thinking skills (HOTS) (Barak \& Dori, 2009). Countries with high achievements in the Programme for International Student Assessment (PISA) focus activities on HOTS and its application in solving real life problems (Schleicher, 2018).

A study conducted by Jensen, McDaniel, Woodard, and Kummer (2014) showed that assessment that focuses on higher order skills can stimulate students to understand the lesson more deeply so that they are not only capable of applying, analyzing and evaluating, but will also be better at remembering the factual knowledge that are taught. On the other hand, questions that only focus on memorizing will not foster a student's skills in critical thinking and applying knowledge.

Referring to previous research, Preus (2012) stated that students that had learning activities involving higher order thinking scored higher on high-stake tests compared to those with learning that focused on basic skills with a broad scope of lessons. Higher order thinking can also be developed since students are in primary schools, including schools with students from various socioeconomic backgrounds, as long as the schools conduct authentic learning (Preus, 2012).

The success of HOTS's development is also determined by the alignment between learning outcomes to be achieved as stated in the curriculum documents and the implemented assessments (FitzPatrick \& Schulz, 2015) because assessment has a close relationship with teaching and learning (Baird, Andrich, Hopfenbeck, \& Stobart, 2017). Research by FitzPatrick and Schulz (2015) about the curriculum and assessment practices of sixth and seventh grade's science units in Canada, which were Columbia, Alberta, Ontario, and Atlantic Canada, showed that the closer the relationship between documented curriculum, learning outcomes and class assessment, the higher the chances were of students developing higher order thinking skills.

The effort of developing higher order thinking skills have also become a concern in Indonesia. In the past few years, the national exams for middle and high schools have included questions categorized as HOTS (antaranews.com, April 22, 2018). According to the Minister of Education and Culture, Muhadjir Effendy, these questions that require higher order thinking skills are necessary to the prepare students for the challenges of the $21^{\text {st }}$ century (antaranews.com, May 23, 2018). However, the implementation of these HOTS questions caused a reaction from students because the questions were considered too difficult (BSNP, 2018).

The use of HOTS questions also spread to primary schools through the national-based school exam. However, these HOTS questions were considered to contribute to the decrease of students' scores. In Yogyakarta, for example, the average score of the national-based school exam decreased by 7 points, from 219 to 212,74 (nasional.tempo.co, June 5 2018). In addition, it was reported that many exam participants complained that the questions in the primary school's the national-based school exam were too difficult, particularly the mathematics problems.

The assessment of HOTS is still a challenge for teachers in many levels of education. The assessment instruments were still dominated by items for measuring LOTS (Budiman \& Jailani, Fensham \& Bellocchia, 2013; McNeill, Gosper, \& Xu, 2012). A study by Retnawati, Djidu, Kartianom, Apino, and Anazifa (2018) involving 27 mathematics teachers of public and private middle schools from seven provinces of Indonesia showed that the teachers' knowledge of 
HOTS was still lacking. In addition, the teachers' abilities for developing students' HOTS, finishing problems which require HOTS, and conducting HOTS assessment were still low. Therefore, the success of the development of higher order thinking skills is also determined by the assessment that is developed and used by teachers. Because of this, teachers need to improve their skills when constructing assessment instruments as one of the competencies that professional teachers need to have. The teachers' ability of conducting an assessment will be reflected on the quality of the instrument that they have made (Jihad \& Haris, 2008).

This research aimed to explore the understanding of primary school teachers in Jakarta and its surrounding areas regarding HOTS and the implementation of HOTS assessment. This research also aimed to describe the quality of HOTS assessment instruments that were constructed by the teachers.

\section{METHOD}

This was a qualitative research involving 10 primary school teachers in Jakarta and its surrounding areas. This qualitative research was chosen because it suited the research's aim, which was to describe primary school teachers' conception about HOTS and how they assess students' higher order thinking skills. Moreover, the researchers also analyzed the HOTS assessment instruments that were constructed by the teachers. Therefore, a qualitative research was a very relevant choice.

Data about the teachers' understanding about HOTS and the processes they went through to construct the assessment instruments were obtained though semi-structured interviews with previously prepared questions. However, the interviewer still had the freedom to probe and elaborate their questions during the interview. The interviews were done to dig up information about teachers' understanding about HOTS and how they implemented the assessment. In addition, the researchers also gave questions to explore backgrounds of teachers regarding the training about HOTS that they have attended, the curriculum used, and the class that they taught.

In accordance to the teachers' agreement, the interviews were recorded and transcribed. The data from the interview were analyzed by referrering to Miles and Huberman which included the steps of (1) data reduction, (2) displaying the data, and (3) drawing a conclusion, verification and interpreting data.

Meanwhile, the data for the HOTS assessment instruments were obtained through the items of HOTS that were made by the teachers. The data of the HOTS assessment instrument constructed by the teachers were analyzed for its validity, referring to basic competencies based on the blue print of every assessment instrument constructed by the teachers. Afterward, each item was analyzed to see its alignment with Bloom's revised taxonomy to determine the level of cognitive process of each item.

\section{FINDINGS AND DISCUSSION}

\section{1 Teachers' Understanding about HOTS}

In general, the research results showed that the teachers were only capable of explaining a partial understanding of HOTS. The majority of the teachers described HOTS as a skill that higher than remembering and understanding. The analyzing skill was the cognitive process most frequently mentioned by the teacher when describing HOTS. For example, Teacher 1, a teacher of a third grade class, stated that: 
"My understanding of HOTS is that they are questions used to measure a child's skill on a certain level, so it is already to the point of understanding, of explaining, identifying, and analyzing the problems. The answer is the result of the student's analysis."

In Bloom's revised taxonomy, applying, analyzing, evaluating, and creating are categorized as higher order thinking (FitzPatrick \& Schulz, 2015). On the other hand, explaining and identifying are still categorized as LOTS. Therefore, there are still many misconceptions regarding HOTS among the teachers. Another conception of HOTS as explained by Teacher 4, was still related to the cognitive process of analyzing, but the teacher elaborated on the meaning of HOTS as a skill of connecting different information and critically analyzing it.

"HOTS is a thinking skill or remembering information and assessments are more about measuring the skills of processing and applying the information, looking for connections from various, different information, and critically analyzing the information."

Analyzing is one of the cognitive processes of HOTS indicated by the skill of differentiating elements from obtained information and finding connections between those elements in a coherent structure (Anderson et al., 2014). The skill of critically analyzing information, as stated by Teacher 4, is a form of critical thinking. One definition by Brookhart (2010) regarding higher order thinking is critical thinking that is characterized by the skill to connect elements of information.

Teacher 8 stated that HOTS was a needed skill for students to face the $21^{\text {st }}$ century, which was conveyed as below:

"In my opinion, HOTS is like a skill that needs to be sharpened during the process of learning. A skill that involves $21^{\text {st }}$ Century Skills or $4 C$ skills (Creativity, Communication, Collaboration, and Critical Thinking) that needs to be practiced by students to reach HOTS." (Teacher 8).

From the interview, there was also a teacher that stated that they have never heard about HOTS.

"I have not heard about it before, so I have not applied the HOTS methods. So for my teaching, I still use lectures, questioning and answers, the usual things. The school has also not given me information and I have not attended any training." (Teacher 7).

The results of the interview show that, in general, the teachers have not comprehensively understood the concept of HOTS. There were no teachers that specifically mentioned evaluating and creating, cognitive processes categorized as HOTS. However, there was an teacher that mentioned them by the terms C5 and C6.

In addition, there were some inaccurate understandings of the concept of HOTS, such as: HOTS is an essay question, HOTS is of higher quality, and HOTS are items that included figures. The findings of this research confirmed the conclusion drawn by Retnawati et al. (2018) that teachers' comprehension of HOTS is still lacking. 


\subsection{Implementation of HOTS}

The interview about the implementation of HOTS resulted in a variety of answers. Three teachers stated that they do not understand how to make HOTS questions, as conveyed by one of the teachers:

"I haven't really understood it yet, so I only make questions, only focusing on if that question is meaningful or not, but not knowing if it's HOTS or not." (Teacher 6).

The teachers that had implemented the assessment of HOTS was mostly on the level of analysis. They still had difficulty in making HOTS questions on the evaluating and creating level. In addition, the teachers are still very dependent on multiple choice questions when assessing HOTS. They think that HOTS questions in the form of essays were still not suitable with the students' skills.

"We have included HOTS in some of the questions. And it's still limited to multiple choice questions." (Teacher 1).

Although the majority of questions made by the teachers were dominated by multiple choice questions, one of the teachers was aware that making multiple choice HOTS questions was more difficult, thus being able to cover only the analyzing cognitive process. To test students' evaluation and creating skills, one of the teachers

) stated that essay questions can serve that purposes.

"To apply it to multiple choice questions is harder, so most of the implementation is on short answer or essay questions. Because HOTS is best used if the multiple choice question is still at C4 because C5 and C6 are more fitting for essay questions." (Teacher 9).

Another teacher stated that to measure HOTS, they made difficult questions in the form of essays.

"I gave difficult questions, mostly in the form of essays." (Teacher 8).

Brookhart (2010) said that one of the principles of assessing higher order thinking is differentiating between the difficulty levels (whether the question is easy or difficult) and complexity levels (whether the question only needs remembering skills or a higher order of thinking). Therefore, a difficult question does not automatically measure HOTS.

The HOTS assessment instruments constructed by the primary school teachers in this research had good content validity, in which each item could measure basic competencies which were the purpose of learning. However, Teacher 9, for example, thought that, teachers were going through a dilemma because basic competencies in the 2013 Curriculum documents for primary schools have yet to include HOTS. The inconsistency between basic competencies as listed in the curriculum and how HOTS questions are being introduced into the national exams has created an internal conflict for teachers that conduct the learning and assessment in class. According to FitzPatrick and Schulz (2015), students will have a greater chance of developing higher order thinking if there is a consistency of the curriculum, learning, and assessment. Because of this, the implementation of HOTS questions in the national exams should be followed by including the cognitive processes categorized as HOTS on curriculum documents. Moreover, the learning and assessment by teachers should also include HOTS. 


\subsection{The Quality of HOTS Assessment Instrument Constructed by the Teachers}

The analysis of the HOTS assessment instrument constructed by the primary school students in this research reveals that there is a different perception between teachers regarding questions categorized as HOTS and the expert who had the cognitive processes of Bloom's revised taxonomy as reference. Teachers tend to perceive the questions that they have made as HOTS questions compared to the perception of the expert. Based on the analysis of 393 multiple choice items that were compiled by the 10 teachers that participated in this research, the amount of questions categorized as HOTS were twice the amount (20,6\%) compared to the questions categorized as HOTS by the expert $(9,9 \%)$. The same can be seen from the 245 essay items that were analyzed in this research. Overall, teachers claimed that $22,0 \%$ of the essay questions that they made were categorized as HOTS, meanwhile it was 10,6\% according to expert. This comparison of multiple choice and essay items as HOTS by the teachers and the expert are illustrated below:

Figure 1

Percentage of HOTS Multiple Choice Questions According to Teachers and Expert

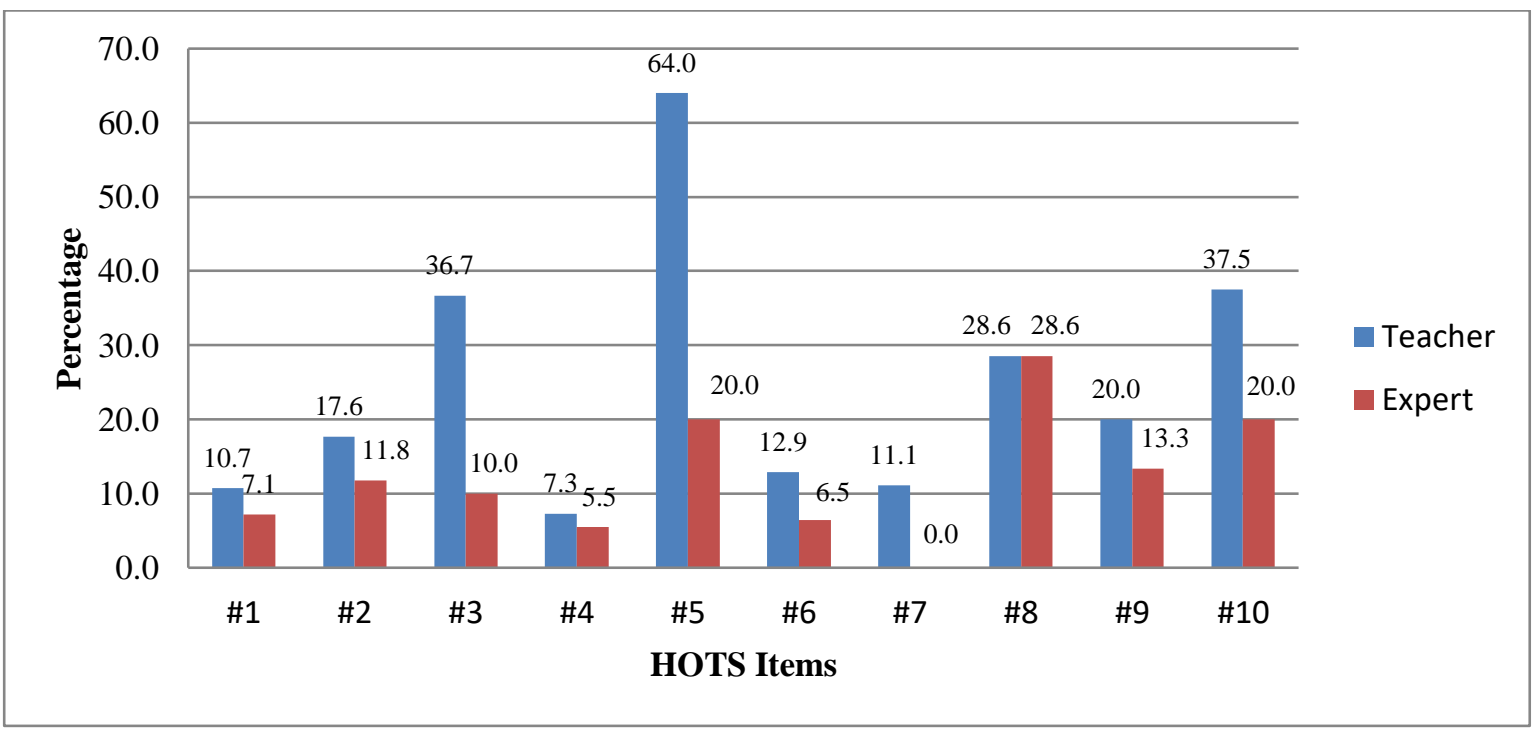


Figure 2

Percentage of HOTS Essay Questions According to Teachers and Expert (\%)

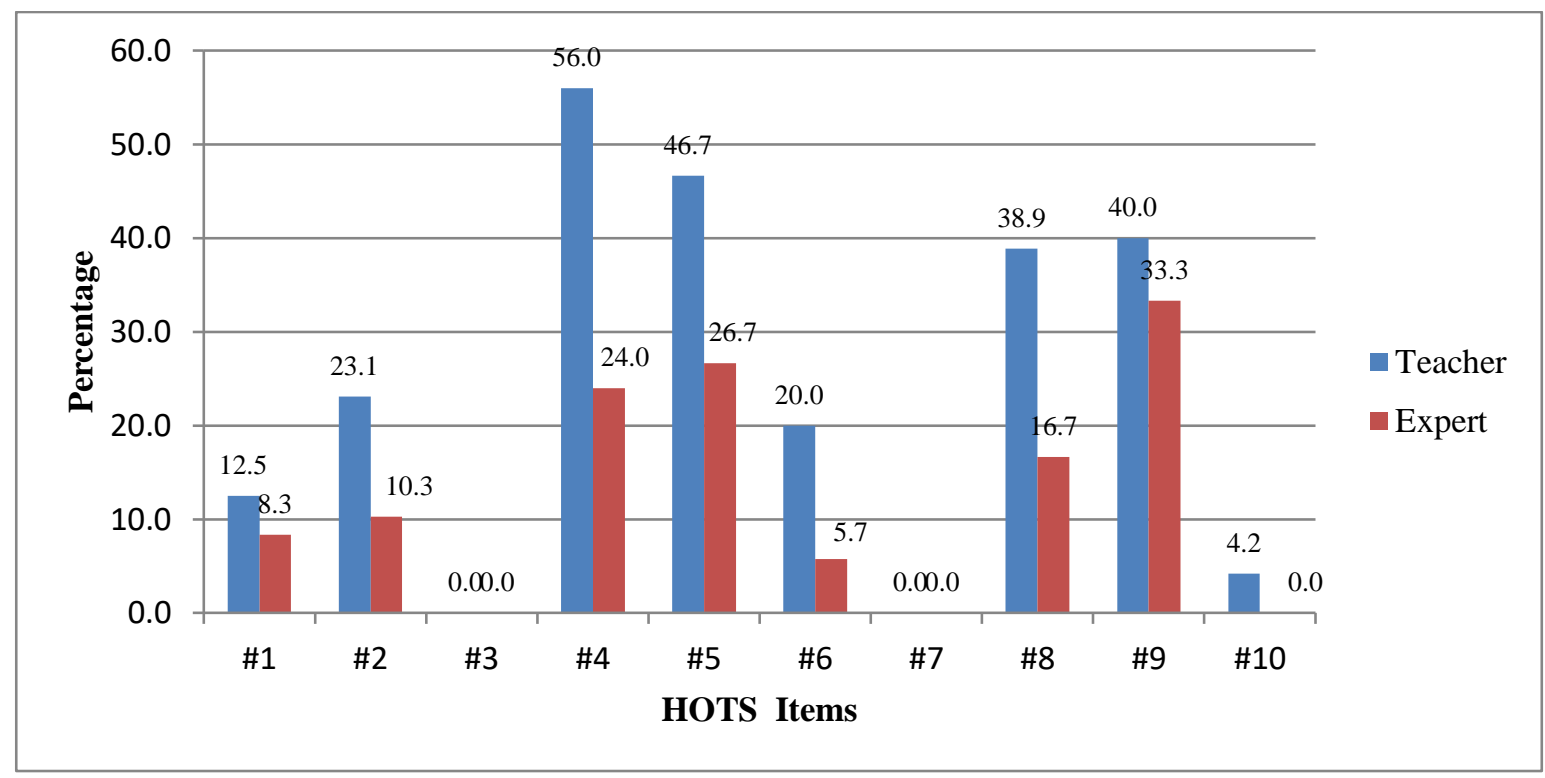

Besides the ambiguous level of cognitive processes, the creative and innovative indicators did not appear in the questions made by the teachers.

\section{CONCLUSIONS}

The primary school teachers that participated in this research were aware of the importance of HOTS to prepare the students to face the challenges of the $21^{\text {st }}$ century. However, their understanding was not comprehensive yet. The majority of the HOTS questions that they made were limited to analysis in the form of multiple choice questions. In addition, there was a misunderstanding about the meaning of HOTS questions, such as HOTS are difficult questions, HOTS questions are word problems or HOTS questions are items that contain figures

The HOTS instrument constructed by the primary school teachers has good content validity, in which each item that they made were able to measure the basic competencies that have become the purpose of learning. However, there was a difference of perception between the teachers and the expert regarding the cognitive level of the items referring to Bloom's revised taxonomy. Teachers tend to perceive the questions that they have made as HOTS questions although those questions were actually remember and understanding questions that were categorized as LOTS. This difference in perception happened because the teachers did not have a comprehensive understanding of HOTS yet.

Alignment between curriculum, instruction, and assessment is needed to develop higher order thinking skills. Teachers also need opportunities to expand their knowledge and skills in developing and implementing HOTS assessment through proper training programs.

\section{Acknowledgments}

The researchers wanted to acknowledge the Research Institute of the University of Muhammadiyah Prof. DR. HAMKA that granted the funding for this research in 2018. 


\section{REFERENCES}

Aksela, M. (2005). Supporting Meaningful Chemistry Learning and Higher-order Thinking through Computer-Assisted Inquiry:A Design Research Approach. [Doctoral Dissertation]. Retrived May 15, 2019 from http://ethesis.helsinki.fi/julkaisut/mat/kemia/vk/aksela/supporti.pdf .

Anderson, L. W. et al. ( 2001). A Taxonomy for Learning, Teaching and Assessing : revision a Bloom's Taxonomy of Education Objective. New York : Addison Wesley Longman, Inc.

Antaranews (2018, April 22). Mendikbud: Soal "HOTS" untuk UN SMP disesuaikan., diakses 29 Juni 2018 Retrieved from http://antaranews.com/mendikbud-soal-hots-untuk-un-smpdisesuaikan

Antaranews (2018, May 23). Mendikbud: Nilai rata-rata UN SMP turun. Retrieved from http://antaranews.com/mendikbud-nilai-rata-rata-un-smp-turun.

Baird, J., Andrich, D., Hopfenbeck, T. N., \& Stobart, G. (2017). Assessment and learning: fields apart?, Assessment in Education: Principles, Policy \& Practice, 24 (3), 317-350, DOI: 10.1080/0969594X.2017.1319337

Barak, M. \& Dori, Y. J.(2009). Enhancing higher order thinking skills among in service science teachers via embedded assessment. Journal of Science Teacher Education, 20, 459-474. DOI 10.1007/s10972-009-9141-z

Brookhart, S. M. (2010). How to assess higher-order thinking skills in your classroom. Alexandria, VA: ASCD.

BSNP (2018, October 5). Penerapan Soal Model HOTS dalam Ujian Nasional Perlu Diimbangi dengan Peningkatan Kemampuan Guru dan Siswa. Retrieved from http://bsnpindonesia.org/2018/04/21/penerapan-soal-model-hots-dalam-ujian-nasional-perlu-diimbangidengan-peningkatan-kemampuan-guru-dan-siswa

Budiman, A., \& Jailani. (2014). Pengembangan instrumen asesmen higher order thinking skill (HOTS) pada mata pelajaran matematika SMP kelas VIII semester 1. Jurnal Riset Pendidikan Matematika, 1(2), 139-150.

Fensham, P. J., \& Bellocchia, A. (2013). Higher order thinking in chemistry curriculum and its assessment. Thinking Skills and Creativity, http://dx.doi.org/10.1016/j.tsc.2013.06.003

FitzPatrick, B., \& Schultz, H. (2015). Do curriculum outcomes and assessment activities in science encourage higher order thinking?. Canadian Journal of Science, Mathematics and Technology Education, 15(2), 136-154 DOI:10.1080/14926156.2015.1014074

Jensen, J. L., McDaniel, M. A., Woodard, S. M., \& Kummer, T. A. (2014). Teaching to the Test...or Testing to Teach: Exams Requiring Higher Order Thinking Skills Encourage Greater Conceptual Understanding, Educ Psychol Rev (2014) 26:307-329.DOI $10.1007 / \mathrm{s} 10648-013-92489$

Nasional Tempo (2018, June 5). Rata-rata Nilai USBN SD di Yogyakarta Menurun pada tahun 2018. Retrieved from http://nasional.tempo.co/rata-rata-nilai-usbn-sd-di-yogyakartamenurun-pada-2018.

McNeill, M., Gospera, M., \& Xu, J. (2012). Assessment choices to target higher order learning outcomes: the power of academic empowerment. Research in Learning Technology, 20, 283-296.

Miles, M. B., \& Huberman, A. M. (1994). Qualitative data analysis (2nd ed.). Thousand Oaks, CA: SAGE Publications, Inc.

Preus, B. (2012). Authentic instruction for 21st century learning: higher order thinking in an inclusive school. American Secondary Education, 40(3), 59-79. 
Retnawati, H., Djidu, H., Kartianom, Apino, E., Anazifa, R.D. (2018). Teachers' knowledge about higher-order thinking skills and its learning strategy. Problems Of Education in the 21st Century, 76( 2), 215-230.

Schleicher, A. (2018). World Class: How to build a 21st-century school system, Strong Performers and Successful Reformers in Education, OECD Publishing, Paris.http://dx.doi.org/10.1787/4789264300002-en

Zohar, A. (2004). Elements of teachers' pedagogical knowledge regarding instruction of higher order thinking. Journal of Science Teacher Education, 293-312 